\title{
Frequency of Rotavirus and Adenovirus in Children with Diarrhea in Sivas Numune Hospital
}

\section{Sivas Numune Hastanesi"ne Başvuran İshalli Çocuklarda Rotavirus ve Adenovirus Sıklığı}

Tuğba Yanık Yalçın¹, Dilara Yıldırım², Sevil Alkan³

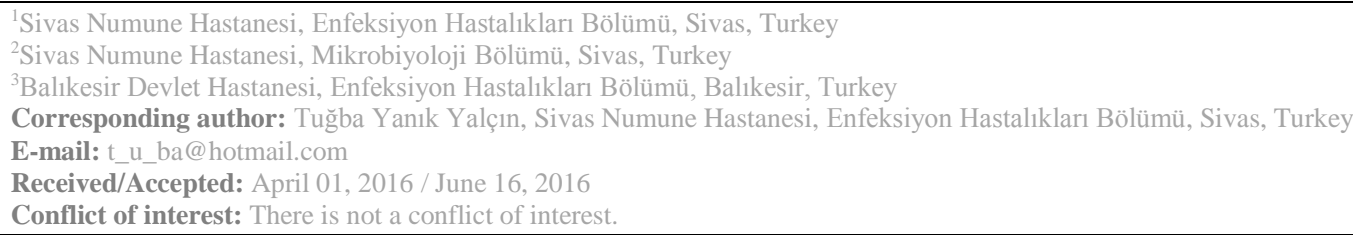

\section{SUMMARY}

Objective: Rotavirus and adenovirus are important infectious agents that occurs in children with severe diarrhea and could have high morbidity and mortality because of water and electrolyte loss. Our aim in this study, is to determine the frequency of rotavirus and adenovirus according to age groups and seasons in children applied pediatry polyclinics with diarrhea complaint.

Method: Between march 2013 and april 2014, 426 fecal sample taken from the patients applied to pediatry and infection disease polyclinics in Sivas Numune Hospital with diarrhea complaint were incorporated to study. This study performed on only one card covered monoclonal antibodies included both two virus with rotavirus and adenovirus quantitative immunochromatographic procedure from fresh fecal samples.

Results: From 426 fecal sample tested in this research, 48 (\%11.3) rotavirus positivities and 11 (\%2.6) adenovirus positivities were detected. The patients were classified as 0-1 age, 2-5 age and olders. There is no difference between seasons and months for the positivity of rotavirus and adenovirus. Additionally, there is no statistical significant difference between rotavirus positivity and adenovirus positivity in 0-1 age, 2-5 age and olders.

Conclusions: Rotavirus and adenovirus infections occur in every season and every age groups. Rotavirus and adenovirus ratios of positivity in our study are similar to other studies in our country. Viral agents must consider in childhood diarrheas and rapid antigen screening tests must be used.

Keywords: Childhood Diarrhea, Rotavirus, Adenovirus.

\section{ÖZET}

Amaç: Rotavirus ve adenovirus çocuklarda şiddetli diyare ile seyreden sıvı ve elektrolit kaybı nedeniyle mortalitesi ve morbiditesi yüksek olabilen önemli bir enfeksiyon etkendir. Bu çalışmadaki amacımız; pediatri ve enfeksiyon hastalıkları polikliniklerine ishal şikayetleri ile başvuran çocuklarda, rotavirus ve adenovirus sıklığını yaş gruplarına ve mevsimlere göre belirlemektir.

Yöntem: Mart 2103 - Nisan 2014 tarihleri arasında Sivas Numune Hastanesi pediatri polikliniğine ishal şikayeti ile başvuran 426 dışkı örneği çalışmaya dahil edildi. Taze dışkı örneklerinden rotavirus ve adenovirus kalitatif immünkromotografik yöntemi (Abon, Hangzhon, China) ile her iki virusu da içeren monoklonal antikorlarla kaplı tek bir kart üzerinde çalışıldı.

Bulgular: Çalışmaya alınan 426 dışkı örneğinden 48(\%11.3) hastada rotavirüs pozitifliği. 11(\%2.6) hastada adenovirüs pozitifliği tespit edildi. Hastalar 0-1 yaş, 2-5 yaş arası ve 5 yaş üstü olarak 
gruplandırıldı. Rotavirüs ve adenovirüs pozitifliğinde mevsimler ve aylar arasında fark yoktu. Ayrıca rotavirüs pozitifliği ile adenovirüs pozitifliği arasında, $0-1$ yaş, $2-5$ yaş arası ve 5 yaş üstü gruplar arasında da istatistiksel olarak anlamlı bir fark görülmedi ( $\mathrm{p}>0.05)$.

Sonuç: Rotavirus ve adenovirus yılın her mevsiminde ve tüm yaş gruplarında görülebilmektedir. Çalışmamız da belirlediğimiz rotavirus adenovirus pozitiflik oranları ülkemizde yapılan diğer çalışmalara yakındır. Çocukluk çağı diyarelerinde viral etkenler akılda tutulmalı ve tanılarına yönelik hızlı antijen tarama testleri kullanılabilmelidir.

Anahtar sözcükler: Çocukluk çağı ishali, Rotavirus, Adenovirus

\section{INTRODUCTION}

Acute gastroenteritis is the most common cause of mortality and morbidity in young children in developed and developing countries. Viruses are responsible for the vast majority of diarrhea during childhood ${ }^{1}$.

Rotavirus among enteropathogenic viruses is the most common responsible agent. In children under five years of age, 527.000 children lost their lives because of fluid and electrolyte loss due to rotavirus infection in 2004 around the world ${ }^{2,3}$.

Although adenovirus is mainly an infectious agent holding respiratory system, it can cause diarrhea complaints by holding the gastrointestinal system. One of the common causes of gastroenteritis after rotaviruses in infants and children is adenovirus. It can be found in the stool during and after upper respiratory tract infection. However, only some serotypes cause gastroenteritis ${ }^{4}$.

In this study, it was aimed to determine the frequency of cases diagnosed with rotavirus and adenovirus among children who applied to the pediatrics department with the complaints of acute gastroenteritis, and to examine its distribution by months, seasons and age groups.

\section{MATERIAL AND METHOD}

The stool samples of 426 patients with suspected rotavirus and adenovirus who applied to Sivas Numune Hospital pediatric and infection disease polyclinics with the complaint of diarrhea between March 2013 and
February 2014 were examined through microbiology records. Rotavirus and adenovirus antigen, from fresh stool samples, was studied on a single card covered with monoclonal antibody containing both viruses separately by qualitative immunochromatographic method (Abon, Hangzhon, China). Patients with positive rotavirus and adenovirus were grouped by the months and seasons they came and their ages. The age range was divided as $0-1$ years, $2-5$ years and above 5 years of age. SPSS 15.0 program was used in the analysis of data. Categorical comparisons were made based on significance test and chisquare of the difference between two averages, $\mathrm{p}<0.05$ was accepted as significant.

\section{RESULTS}

Among 426 stool samples with the complaint of diarrhea included in the study, rotavirus positivity was detected in 48 (11.3\%) patients; adenovirus positivity was detected in $11(2.6 \%)$ patients, and co-positivity of both viruses was detected in $2(0.46 \%)$ patients. Patients were grouped as 0-1 years, 2-5 years and above 5 years of age. An increase was observed in the percentage of rotavirus and adenovirus positivity during spring and autumn though it was not statistically significant (Table 1). Furthermore, a statistically significant difference was not observed between rotavirus positivity percentage and adenovirus positivity percentage, and between the groups of 0-1 years, 2-5 years and above 5 years of age (Table 2) $(\mathrm{p}>0.05)$. 
Table 1. Rotavirus and Adenovirus positivity percentages according to season

\begin{tabular}{lllll}
\hline & \multicolumn{3}{l}{ Rotavirus } & \multicolumn{2}{l}{ Adenovirus } \\
\cline { 2 - 5 } & Positive $\mathrm{n}(\%)$ & Negative $\mathrm{n}(\%)$ & $\begin{array}{l}\text { Positive } \mathrm{n}(\%) \\
\mathrm{n}(\%)\end{array}$ & Negative \\
Spring & $20(12.7)$ & $137(87.3)$ & $3(1.9)$ & $154(98.1)$ \\
Summer & $4(4.1)$ & $94(95.9)$ & $4(4.1)$ & $94(95.9)$ \\
Autumn & $15(15.5)$ & $82(84.5)$ & $3(3.1)$ & $94(96.9)$ \\
Winter & $9(12.2)$ & $65(87.8)$ & $1(1.4)$ & $73(98.6)$ \\
Total & $48(11.3)$ & $378(88.7)$ & $11(2.6)$ & $415(97.4)$ \\
\hline Rotavirus: $\mathrm{x}^{2}=7.16 \mathrm{p}=0.06$ & Adenovirus: $\mathrm{x}^{2}=1.73 \mathrm{p}=0.6(\mathrm{p}>0.05)$ &
\end{tabular}

Table 2. Rotavirus and Adenovirus positivity percentages by age group

\begin{tabular}{|c|c|c|c|c|}
\hline & \multicolumn{2}{|l|}{ Rotavirus } & \multicolumn{2}{|l|}{ Adenovirus } \\
\hline & Positive $\mathrm{n}(\%)$ & Negative $\mathrm{n}(\%)$ & $\begin{array}{l}\text { Positive } \mathrm{n}(\%) \\
\mathrm{n}(\%)\end{array}$ & Negative \\
\hline $0-1$ age & $8(7.8 \%)$ & $95(92.2)$ & 1(1) & $102(99)$ \\
\hline $2-5$ age & $33(14.6 \%)$ & 193(85.4) & $9(4.0)$ & 217(96.7) \\
\hline $\begin{array}{l}\text { Over the age } \\
\text { of } 5\end{array}$ & $7(7.2 \%)$ & $90(92.8)$ & $1(1)$ & $96(99)$ \\
\hline Total & $48(11.3 \%)$ & $378(88.7)$ & $11(2.6)$ & $415(97.4)$ \\
\hline
\end{tabular}

\section{DISCUSSION}

Rotavirus leads more than 100 million patients to apply to emergency services and outpatient clinics every year in developed and developing countries. Children around the world are infected with rotavirus by the age of 2 and 3 . However, the mortality and morbidity of the disease are higher in less developed countries and developing countries ${ }^{5}$. Rotavirus infection was determined as $25 \%$ in children with diarrhea in Africa in a multicenter study involving 27 countries, which was carried out between 1976 and $2006^{6} .40 .6 \%$ positivity was detected in a study involving European countries carried out in $2007^{7}$.

According to the data of the World Health Organization (WHO), rotavirus positivity is averagely reported as $20 \%$ and $40 \%$ in Europe, $5 \%$ and $25 \%$ in America, 30\% and 50\% in Asia and 10\% and $65 \%$ in Africa ${ }^{8}$. The methods used in the studies carried out in our country and the rotavirus, adenovirus positivity percentages are given in the following table (Table 3). Rotavirus positivity ranges between $9.7 \%$ and $36.1 \%$, adenovirus positivity ranges between $1.06 \%$ and $9.3 \% \%^{9-17}$. The rotavirus positivity ratio in all age groups was detected as $11.3 \%$ in this study.

In terms of seasonal distribution of rotavirus infection, while it seems to increase during autumn according to a study by Meral et $\mathrm{al}^{5}$, it was detected an increase in autumn and winter in a study by Khalili et a ${ }^{18}$. On the other hand, we observed an increment in the percentage of rotavirus positivity in spring and autumn in our study.

Adenovirus infections may occur in a large portion of the year but are slightly more common during the summer months. As a result of the studies carried out in Europe, Asia, North and South America, enteric adenoviruses were shown to be active in $3.1 \%$ and $13.5 \%$ of childhood gastroenteritis ${ }^{11}$. When studies carried out in different regions in different years in our country are taken into account, the decrease in infection rates draws attention (Table 3). Personal vaccinations, although they are not included in routine vaccination program 
by the Ministry of Health, and the increase in social consciousness can explain this decrease.

The adenovirus positivity is $2.6 \%$ in this study. Rotavirus and adenovirus positivity percentages in this study are close to other studies. Different results can also be explained by the fact that the antibodiesinthe immunochromatographic test we used reflect the serotypes in our region less.
The monoclonal antibodies in kits studied should contain the serotypes that are observed more frequently especially in our region/our country. Therefore, the determination of the common serotypes in our country and the preparation of domestic kits covered with more specific antibodies for them will provide a more accurate diagnosis.

Table 3. Rotavirus and Adenovirus study results in our country

\begin{tabular}{|c|c|c|c|c|c|}
\hline $\begin{array}{l}\text { Study } \\
\text { team }\end{array}$ & Method & Year & $\begin{array}{l}\text { Rotavirus\%/ } \\
\text { Adenovirus\% }\end{array}$ & City & $\begin{array}{l}\text { Case } \\
\text { number }\end{array}$ \\
\hline $\begin{array}{l}\text { Parlak } \\
\text { ve } \text { ark }^{9}\end{array}$ & Latex agglutination & 1994 & $\% 36.17 /-$ & Erzurum & 94 \\
\hline $\begin{array}{l}\text { Gül ve } \\
\operatorname{ark}^{10}\end{array}$ & $\begin{array}{l}\text { RIDA Quick Rota } \\
\text { Adeno Kombi R- } \\
\text { Biopharm AG, Germany } \\
\text { Latex agglutination }\end{array}$ & 2005 & $\% 25.7 / \% 4.7$ & Kahramanmaraş & 148 \\
\hline $\begin{array}{l}\text { Biçer } \\
\text { ve } \operatorname{ark}^{11}\end{array}$ & Immunochromatographic & 2007 & $-1 \% 9.3$ & İstanbul & 1941 \\
\hline $\begin{array}{l}\text { Altındiş } \\
\text { ve } \operatorname{ark}^{12}\end{array}$ & $\begin{array}{l}\text { DiarlexRota Orion } \\
\text { DiagnosticaUSANovum } \\
\text { DiagGmbH Germany } \\
\text { Latex agglutination }\end{array}$ & 2008 & $\begin{array}{l}\% 12.5 / \% 4.5 \\
\% 3.2 / \% 1.06\end{array}$ & Afyonkarahisar & $\begin{array}{l}112 \text { (case) } \\
94(\text { control })\end{array}$ \\
\hline $\begin{array}{l}\text { Akan } \\
\text { ve } \operatorname{ark}^{13}\end{array}$ & $\begin{array}{l}\text { Cer Test Biotec Spain } \\
\text { Immunochromatographic }\end{array}$ & 2009 & $\% 18.7 / \% 8.9$ & İstanbul & 672 \\
\hline $\begin{array}{l}\text { İlktaç } \\
\text { ve } \operatorname{ark}^{14}\end{array}$ & $\begin{array}{l}\text { Combi-Strip, CORIS } \\
\text { BioConcept, Belçika; } \\
\text { Rotavirus Rapid Combo } \\
\text { Test Device, MK Bio, } \\
\text { Almanya } \\
\text { Immunochromatographic }\end{array}$ & $\begin{array}{l}2006 \\
2007 \\
2008 \\
2009 \\
2010\end{array}$ & $\begin{array}{ll}\% & 19.2 /- \\
\% & 14.5 /- \\
\% & 17.3 /- \\
\% & 16.6 /- \\
\% & 11.0 /-\end{array}$ & İstanbul & 11.711 \\
\hline $\begin{array}{l}\text { Meral } \\
\text { ve } \operatorname{ark}^{15}\end{array}$ & $\begin{array}{l}\text { Rotoclone } \\
\text { (ELISA) }\end{array}$ & 2011 & $\% 21.2 /-$ & Ankara & 251 \\
\hline $\begin{array}{l}\text { Köksal } \\
\text { ve } \operatorname{ark}^{16}\end{array}$ & $\begin{array}{l}\text { Combi-Strip, CORIS } \\
\text { BioConcept, Belçika } \\
\text { Immunochromatographic }\end{array}$ & 2013 & $\% 28.3 /-$ & Ankara & 240 \\
\hline $\begin{array}{l}\text { Inan ve } \\
\operatorname{ark}^{17}\end{array}$ & $\begin{array}{l}\text { Vikia }{ }^{\circledR} \text { Rota Adeno } \\
\text { bioMérieux Diagnostic } \\
\text { Immunochromatographic }\end{array}$ & 2014 & $\% 9.7 / \% 7.5$ & İstanbul & 435 \\
\hline
\end{tabular}

\section{REFERENCES}

1. Oh DY, Gaedicke G, Schreier E. Viral agents of acute gastroenteritis in German children: prevalence and molecular diversity. J Med Virol 2003; 71: 82-93.

2. Neuzil MK, Armah GE, Parashar UD, Steele AD. Rotavirus in Africa: shifting the focus to disease prevention. $J$ Infect Dis 2010; 202(1):1-4.

3. Delayed Onset and Diminished Magnitude of Rotavirus Activity United States, November 2007-May 2008.MMWR 2008; 57: 25.

4. Adenovirus Infections. In: Pickering LK, Baker CJ, Kimberlin DW, Long 
SS, eds. 2009 Red Book: Report of the Committee on Infectious Diseases. 28th ed. Elk Grove Village, IL: Am Acad Pediatr 2009: 204-6.

5. Meral M, Bozdayı G, Özkan S, Dalgiç B, Alp G, Ahmed K. Akut gastroenteritli çocuklarda rotavirus prevalans1, serotip ve elektroferotip dağglımı. Mik Bült 2011; 45: 104112.

6. Waggie Z, Hawkridge A, Hussey GD. Review of Rotavirus Studies in Africa: 1976-2006.JID 2010; 202: 23-33.

7. Damme PV, Giaquinto C, Maxwell M, Todd P, Wielen MV. Distribution of rotavirus genotypes in Europe, 2004-2005: the reveal study. J Infect Dis 2007; 195: 17-2.

8. World Health Organization (WHO). Global Rotavirus Information and Surveillance Bulletin, 2011; Vol:3, WHO Press, Geneva.

9. Parlak M, Selimoğlu M A, Energin M, Taşyaran M A, Özkurt Z. 0-2 yaş grubu çocuklarda ishal etyolojisi ve rotavirüsün önemi. $\mathrm{T}$ Klin Gastroenterohepatoloji 1995; 6: 7680.

10. Gül M, Garipardıç M, Çıragil P, Aral M, Karabiber H, Güler İ. 0-5 yaş aras1 gastroenteritli çocuklarda rotavirüs ve adenovirüs tip 40/41 araştırılması. Ankem Derg 2005; 19: 64-67.

11. Biçer S, Şahin GT, Koncay B, Gemici H, Engerek N, Ulucaklı Ö, Özlü N, Şiraneci R. Çocuklarda Adenovirüs Gastroenteriti Olgularının Sıklığı. Medical Journal of Bakırköy 2009; 5: 6-10.
12. Altındiş $M$, Beştepe $G$, Çeri A, Yavru S, Kalayc1 R. Akut ishal yakınmalı çocuklarda rotavirüs ve enterik adenovirüs sıklığı. S.D.Ü. Tip Fak. Derg 2008; 15: 17-20.

13. Akan $H$, İzbırak $G$, Gürol $Y$, Sarıkaya S, Gündüz T S, Yılmaz G, Hayran O, Vitrinel A. Rotavirus and adenovirus frequency among patients with acute gastroenteritis and their relationship to clinical parameters: a retrospective study in Turkey. Asia Pacific Family Medicine 2009; 8: 8

14. İlktaç M, Şahin A, Nazik H, Öngen B. Akut gastroenteritli çocuklarda rotavirus sıklığının araştırılması ve rotavirus sezonunun takibi: Beş yıllık sonuçların değerlendirilmesi. Ankem Derg 2012; 26: 25-9.

15. Meral M, Bozdayı G, Özkan S, Dalgiç B, Alp G, Ahmed K. Akut gastroenteritli çocuklarda rotavirus prevalans1, serotip ve elektroferotip dağılımı. Mik Bült 2011; 45: 104-12.

16. Köksal AO, Köksal T. Ankara'da 05 yaş arası akut gastroenteritli çocuklarda rotavirus sıklığı. Yeni Tip Dergisi 2013; 30: 121-3.

17. İnan $\mathrm{N}$, Ünsur $\mathrm{E} \mathrm{K}$, Demirel $\mathrm{A}$, Mamçu D, Sönmez E, Arısoy A. Akut viral gastroenterit öntanılı vakalarda rotavirus, adenovirus ve norovirus sıklı̆̆ının araştırılması. Ankem Derg 2014; 28: 14-9.

18. Khalili B, Cuevas LE, Reisi N, Dove W, Cunliffe NA, Hart CA. Epidemiology of rotavirus diarrhoea in Iranian children. J Med Virol 2004; 73: 309-12. 